\title{
HOW DO CONCERNS ABOUT ORGANIZATIONAL FAIRNESS AND PROFILING AFFECT INDIVIDUALS' FEELING OF ALIENATION?
}

\author{
Joseph S. Mollick, Texas A\&M University-Corpus Christi, jsm6337@yahoo.com
}

\begin{abstract}
We survey an organization's customers who are subjected to information-intensive organizational processes to find out which of their concerns about organizational information management practices correlate with their feeling of alienation from an organization. Using data collected from students of a large university in the North Eastern USA, we find that students' concern about organizational fairness (X1) of information management practices in general and their concern about use of data for personal profiling (X2) correlate with their feeling of alienation (Y) from their university.
\end{abstract}

Keywords: Fairness, information management, profiling, alienation, university, students

\section{INTRODUCTION}

Recently, passport related files of three U.S. presidential candidates were breached and the news was broadcast in major Cable-TV channels and newspapers. Many such events occur in different organizations that do not get as much media attention. Events like this calls us to examine how fears and concerns about unfair events like these affect individuals' relationships with organizations. As organizations use databases and Internet technologies they become increasingly information-intensive [14]. The data that organizations collect about different stakeholders such as employees and customers are stored in databases and shared through computer networks with parties inside and outside organizational boundaries. The individuals about whom data are collected feel different types of concerns about how organizations manage information about individuals. We identify two dimensions of individuals' concerns about organizational information management practices and examine their effects on individuals' feeling of alienation (Y) from the organization about which they are concerned. The first of the two concerns is an individual's concern about organizational fairness in the way personal information about customers is managed (X1). The second concern is an individual's concern about organizational use of data for personal profiling (X2). We choose to conduct our study in an information-intensive relational context such as the kind that exists between students and a university.

\section{LITERATURE REVIEW}

\section{Concern about Fairness of Organizational Information Management (X1)}

One's worry about how fair and balanced organizations are in managing competing interests among different stakeholders of information collected, stored and managed by organizations is one concern that has been reported by information ethics scholars [26, 27] and others. Concerns about fairness of information management practices is ancient but the use of new information and communications technologies by organizations and individuals warrant individuals, organizations and societies to examine the fairness concerns of different stakeholders of information . For example, concern about the fair use of RFID by organizations is a current and relevant question [21, 25]. Whether a specific organizational practice is perceived fair or not and how concerned individual members or customers of an organization feel about the fairness of an organization's information management activities need to be continuously measured and monitored by managers and policy makers because customers' fears and concerns can have negative consequences for relationships between organizations and their members or customers. What could be some of the negative consequences of customers' concern about organizational fairness in the domain of information management? In light of equity theory and theories of justice, it can be said that concern about fairness will lead to a feeling of alienation, a lower motivation to belong to an organization, and a lower motivation to cooperate. For example, when asked to fill up a form or participate in a survey, students may not volunteer to cooperate. If coerced or forced to cooperation with an organization that they perceive is unfair, concern about fairness may even lead members to protest, bring law suits or participate in a violent revolt against the organization or institution that is held responsible for unfairly handling information about customers. By examining with empirical data how concern about fairness may correlate with individual end-users' feeling of alienation, managers can be convinced about the importance of working to reduce customers' concern about the fairness of organizational information management practices. 


\section{Concern about Use of Data for Personal Profiling (X2)}

Individuals' concern about use of data for personal profiling has been mentioned in research literature in many areas of study such as law enforcement, statistical modeling, economics, marketing, database management, information systems and e-commerce research. In the area of law enforcement, policies that make search rates vary with personal attributes are variously defended as essential to effective law enforcement and denounced as unfair to classes of persons subjected to relatively high search rates. The practice of aggregating data from different databases and creating profiles of individuals by using aggregated data [23, 39] has been documented as a cause of concern for individuals. This aggregated data or profiling technique can be used by organizations to implement strategies such as tracking individuals for target marketing, micromarketing, personalization of products and services and for unwanted advertisements or junk mail. The Internet is increasingly being used as a medium to collect information for consumer profiling. However, attempts at data collection face potential difficulties due to consumers' unwillingness to provide personal information Students' concern about use of data for personal profiling $\left(\mathrm{X}_{2}\right)$ refers to students' fear that an organization is not protecting customers' best interest and is unfairly taking advantage of the asymmetry of information [1] about uses of customer information and the resulting information power [27]. We examine the effect of this concern on one's feeling of alienation [2, 35, 36, 37]. The practical motivation to examine this effect is to help managers and policy makers better understand the effects of personal profiling on customers' feeling of alienation.

\section{Feeling of Alienation (Y)}

The dependent variable in this study is an individual customers' feeling of alienation from an organization. The customers are students and the organization is a university. Alienation (Y) can be defined as the degree to which a consumer has negative beliefs and is alienated from universities in general with respect to personal information management practices [2, 30, 31].

\section{Organization Theory and Alienation (Y)}

Some organizations internalize their customers for a mutually beneficial relationship[43]. Students can be thought of as customers who have been internalized by their university. In the context of an existing relationship between an organization and its internalized customers, members have a sense of belonging [3] and membership [38], and mutual dependency [13]. Internalized customers who carry out their transactions with their organization in the context of a reciprocal relationship operate on the basis of an expectation of good faith that their organization will be ethical, trustworthy, procedurally fair and just in how it manages their personal information. Alienation can be viewed as a feeling that arises when the positive sense of belonging is perceived by customers as exploitative. Alienated individuals perceive that their positive expectations are unfulfilled, ignored, neglected, violated or abused by their organization.

\section{Information-intensive Organizations}

We have chosen to study the effects of privacy concerns in the context of a relationship between students and their university because of the information-intensive nature of these individualorganization relationships. Peter Drucker [14] predicted that organizations of the future would become increasingly information-based such as hospitals and universities. Organizations such as universities are expected to be conscience-carriers [27] and moral agents in how they use information-power over different stakeholders [15]. Sources of power include information-based organizations' ability to collect, access, store, possess, legally own, control, share, communicate and buy or sell information about different stakeholders. Organizations are networks among individuals within and around an invisible legal entity. As such, different parties to the social network can be subjected to indignity, injustice and harm because of what information-based organizations do or fail to do with regard to ensuring the fairness access to and disclosure or sharing of information about individuals. Many kinds of harms can befall customers because of improper access to or disclosure and sharing of personal data. One of the most feared consequences for customers is identity theft. When exposed to the threat or possibility of violation of the terms of a social-psychological contract of information exchange, an individual may feel alienated. The attitude that an affected party develops, such as a feeling of alienation, is not so much toward an individual employee of the organization, as toward the organization as a whole and the institution it represents because students might not know the exact point within the organizational hierarchy or processes where responsibility should be placed and where their feeling of alienation should be directed to. 


\section{THE RESEARCH MODEL AND HYPOTHESES}

What could be the effects of the concern about fairness and balance (X1) and the concern about the practice of computer profiling (X2) on an individuals' feeling of alienation (Y)? It is hypothesize that when individuals have worries and concerns about the fairness of organizational information management practices, they are expected to feel alienated from organizations that unfairly exercise enormous information power over them. This prediction is based on the theory of balance of power among stakeholders of organizations [38], the theory of informational asymmetry [1] and the theory of social and psychological contract. The discussion presented above can be summarized using the research model presented in Figure 1.

Figure 1: The Research Model

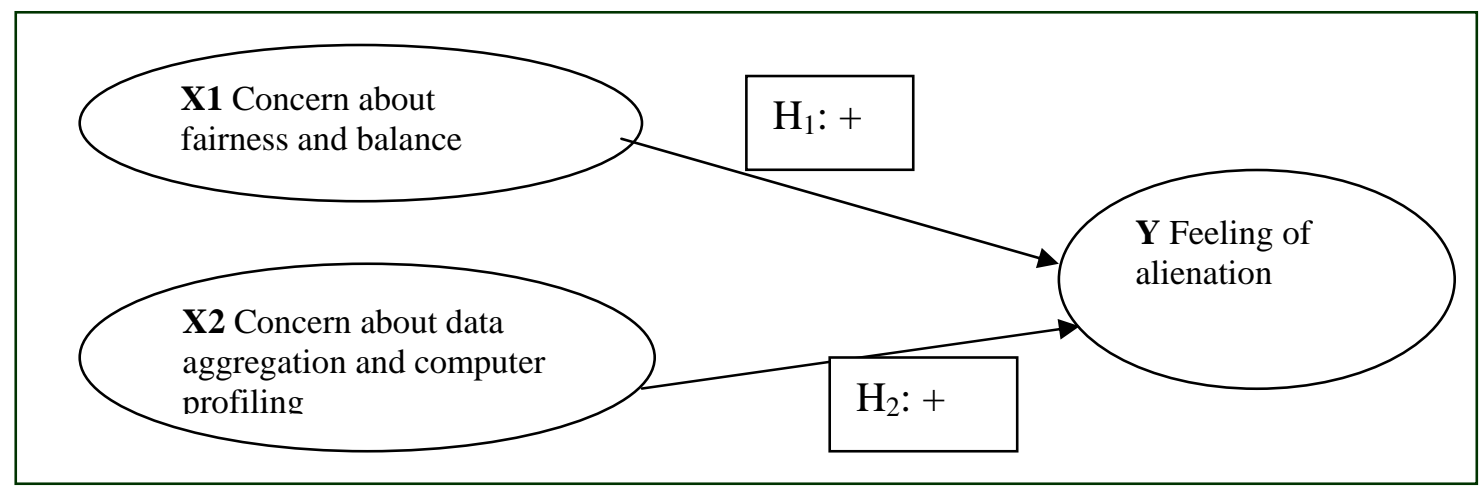

\section{The Dependent Variable (Y): Alienation}

Social thinkers such as Plato, Hegel, Marx, Weber and others have expressed concerns about one's relationship to the society in which one lives and to which one belongs. One such concern is that of alienation of an individual or a group by an organization, by an industry or by a larger society. Today's society is dominated by organizations and organizations are dominated by computerized information systems. Alienation is contextual and has been defined and measured differently under labels such as political alienation [11], social alienation [32], and consumer alienation from the marketplace [2]. Allison's instrument has been adapted to measure students' feeling of alienation from universities with regard to data privacy and security management practices. Alienation is a feeling of separation that involves sentiments of powerlessness, isolation and self-estrangement [2]. It is important to study and understand customers' alienation because customers can respond to alienation in the form of poor performance or dropping out from school, legal or political activism, rebellion, non-cooperation, or even violence [16] against the organizational or social entity they hold responsible for their alienation.

Most prior studies dealing with customer's alienation focused on its sources and consequences but not in the context of customers' concerns about fairness of information management practices and use of data for profiling. One exception is Westin's [46] study that investigated customers' alienation resulting from privacy concerns. Westin [46] found that U.S. citizens felt alienated by government's data collection practices because of their privacy concerns. It has been documented that customers whose complaints are ignored feel alienated. In the context of privacy, an extended, generalized argument can be made that students whose privacy complaints and concerns are ignored will feel alienated. An organizational strategy of growth by merger and acquisition can be a source of alienation for customers [20] because customers' privacy is lost and their risks of exposure and harm are increased. In the context of this study, an analogy can be made that information sharing among different branches or among different units of a large university or university system will be a privacy concern which may cause students to feel alienated. Organizations and regulators need to ask and evaluate if information security policies are satisfactory or not. If organizational activities in the domain of data privacy and security management are perceived by students as unsatisfactory, unfriendly, risky, privacy-invasive and unsafe, the result can be that students will feel alienated. 


\section{Organizational ethics, records management and alienation}

Customers evaluate organizational practices according to their ethical and moral concepts and form judgments as to whether a particular practice should be viewed as good for their well being or should be viewed as an expression of lack of professional care and ethical responsibility on the part of the organization. Ethical tensions in the domain of organizational information management systems develop from conflicts between the differing and, often, conflicting interests of an organization's owners, employees, customers, suppliers, partners, and governmental agencies. For example, using social security numbers as student ID can be a source of efficiency and convenience for a university system's information system designers, administrators, and managers of student records. However, this same practice can compromise students' privacy and security and be a cause of a sense of discomfort, anguish, and insecurity that can lead to their sense of alienation. Social security numbers can be the magic number for data aggregation and profiling purposes and this can be a source of great harm for students. Additionally, the collection of other types of data can be a cause of concern for students. For example, collection, disclosure, sharing or aggregating data about one's race and, life-style, sexual orientation can be a source of alienation for some students.

\section{Research Hypotheses (Hi)}

The discussions presented above can be summarized in the form of two research hypotheses.

$\mathbf{H}_{\mathbf{1}}$ : The higher students' concern about fairness of organizational management practices (X1), the higher their feeling of being alienated $(\mathrm{Y})$ by their university. It is expected that there is a positive correlation between $\mathrm{X}_{1}$ and $\mathrm{Y} .\left(B_{1} \mathrm{X}_{1}>0\right)$.

$\mathbf{H}_{2}$ : The higher the level of concern about use of data for personal profiling $\left(\mathrm{X}_{2}\right)$, the higher the level of alienation( $\mathrm{Y})$. It is expected that there is a positive correlation between $\mathrm{X}_{2}$ and $\mathrm{Y}$. $\left(B_{2} \mathrm{X}_{2}>0\right)$.

\section{SAMPLE, DATA AND METHODOLOGY}

We collected data from 187 students from a large university in the U.S. There were no instances of missing data because the survey was set up online in a way that did not allow respondents to submit the survey without answering all the questions. Students got extra credit points for participating in the survey. Out of 220 students we solicited, 187 completed the survey. Because of this high response rate, nonresponse bias, if any existed, would not be high. Of the 187 students, 37 were graduate business students and
150 were undergraduate business students. The percentage of male (52\%) and female (48\%) students were almost equal. The age of the students in the sample had a mean of 23.22 years and a standard deviation of 5.26 years. There was no statistically significant correlation between age and alienation $(\mathrm{r}=\mathrm{-}$ 0.003565). The mean alienation scores for graduates and undergraduates, male and female were not statistically significantly different.

The variable X1 measures a student's level of concern about fairness and balance in handling information about students. A high score indicates the respondent's strength of the belief that relevant parties to information should be treated fairly, in a balanced way so that one party does not get unfairly hurt by another party's claim of right to information. The independent variable X2 measures the extent to which a student is concerned about being profiled through matching and or aggregating activities carried out with data about students stored in different databases. The dependent variable $\mathrm{Y}$ measures a respondent's feeling of alienation--the sentiment that an organization such as university does not care about the well being of its individual customers such as students. The seven items to measure alienation were from [2] and [36]. The items to measure $\mathrm{X} 1$ and $\mathrm{X} 2$ were taken from [27]. Values for X1, X2 and Y can range from a low of 1 to a high of 7. All items are presented in Appendix A.

\section{Reliability of the Scales of Measurement}

To assess the internal consistency of the multi-item scales of measurement, Cronbach's alpha values were computed for each of the three constructs $\mathrm{Y}, \mathrm{X}_{1}$ and $\mathrm{X}$ Table 1 shows that constructs $\mathrm{Y}$ and $\mathrm{X}_{2}$ have Cronbach's alpha values above .70 and the value for $\mathrm{X}_{1}$ is above .60. The generally agreed upon lower limit for Cronbach's alpha is .70 [18] However, the acceptable lower limit may decrease to .60 for exploratory research. Thus, the values in Table1 indicate that the reliability of all three constructs: concern about fairness of data management (X1), concern about use of data for profiling $\left(\mathrm{X}_{2}\right)$ and feeling of alienation( $\left.\mathrm{Y}\right)$ are acceptable even though the reliability of construct $\mathrm{X}_{1}$ is acceptable on the basis of the argument that this research was exploratory rather than confirmatory. 


\begin{tabular}{|r|r|l|}
\hline \multicolumn{2}{|c|}{ Table 1: Reliability Analysis--Scale (Alpha) } \\
\hline & $\begin{array}{r}\text { Cronbach's } \\
\text { Alpha }\end{array}$ & $\begin{array}{l}\text { Cronbach's Alpha Based on } \\
\text { Standardized Items }\end{array}$ \\
\hline $\begin{array}{r}\text { FairnessConcern } \\
\text { (X1), 4 items }\end{array}$ & 0.6370 & 0.6410 \\
\hline $\begin{array}{r}\text { ProfilingConcern } \\
\text { (X2), 3 items }\end{array}$ & 0.7726 & 0.7715 \\
\hline $\begin{array}{r}\text { Alienation (Y), 7 } \\
\text { items }\end{array}$ & 0.7943 & 0.7870 \\
\hline
\end{tabular}

\section{RESULTS}

Table 2 shows the means, standard deviationis, correlation coefficients and p-values associated with the correlation coefficients. The mean score for concern about fairness is higher than the mean score for concern about profiling. With $99 \%$ confidence it can be said that the correlation between $\mathrm{X} 1$ and $\mathrm{Y}$ and the correlation between $\mathrm{X} 2$ and $\mathrm{Y}$ are both statistically significantly higher than zero. Thus, $\mathrm{H} 1$ and $\mathrm{H} 2$ are supported. The correlation between X1 and X2 is well below .70 which indicates that a multiple regression model is appropriate because there is no problem of multicollinearity.

\begin{tabular}{|r|r|r|r|r|}
\hline \multicolumn{7}{|c|}{ Table 2: Means, Standard Deviations [S], correlations [r] and p-values } \\
\hline & Mean & $\mathrm{S}$ & $\mathrm{X} 1$ & $\mathrm{X} 2$ \\
\hline ConcernFairness (X1) & 5.17 & 0.78 & & \\
\hline & & & $0.2584^{* *}$ & \\
ConcernProfiling (X2) & 4.96 & 1.20 & 0.0002 & \\
\hline & & & $0.2548^{* *}$ & $0.2810^{* *}$ \\
\cline { 5 - 6 } & & & 0.0002 & 0.0000 \\
\hline
\end{tabular}

**Correlation is significant at the 0.01 level (1-tailed).

The results of a multiple regression model are presented in Table 3 imply with over 99\% confidence that the estimated multiple regression model is Table 3: Regression Statistics

\begin{tabular}{lr}
\hline Multiple R & 0.3384 \\
R Square & 0.1145 \\
Adjusted R Square & 0.1049 \\
Standard Error & 0.8878 \\
Observations & 187 \\
\hline
\end{tabular}

ANOVA

\begin{tabular}{lrrrrr}
\hline & df & SS & MS & F & Significance F \\
\hline Regression & 2 & 18.75 & 9.38 & 11.90 & $\mathbf{0 . 0 0 0 0 1 4}$ \\
Residual & 184 & 145.02 & 0.79 & & \\
Total & 186 & 163.77 & & & \\
\hline
\end{tabular}

\begin{tabular}{|c|c|c|c|c|c|c|}
\hline & & Standard & & 1-tailed & & \\
\hline & Coefficients & Error & t Stat & P-value & Lower 95\% & Upper 95\% \\
\hline Intercept & 2.0304 & 0.4653 & 4.363 & 0.000011 & 1.1123 & 2.9484 \\
\hline ConcernFairness (X1) & 0.2343 & 0.0862 & 2.719 & 0.003591 & 0.0643 & 0.4044 \\
\hline ConcernProfiling (X2) & 0.1807 & 0.0563 & 3.210 & 0.000783 & 0.0697 & 0.2918 \\
\hline
\end{tabular}

statistically significant and both $\mathrm{X} 1$ and $\mathrm{X} 2$ are positively related to $\mathrm{Y}$. Thus, $\mathrm{H} 1$ and $\mathrm{H} 2$ are supported. 


\section{DISCUSSION AND FUTURE RESEARCH}

The results of this study have implications for managers of information intensive organizations such as universities. Concern about fairness may lead to customers' feeling of alienation. Likewise, customers' concern about use of data for profiling may lead to customers' feeling of alienation. The implication is that to mitigate individuals' feeling of alienation, organizations should adopt transparently fair and balanced policies that govern the management of information about individuals stored in organizational databases. Likewise, computer matching should be minimized. Organizations can mitigate customers' feeling of alienation by adequately explaining conditions that warrant computer profiling to protect and promote the best interest of individuals from or about whom data are collected. Transparency and open communications can reduce the level of customers' concerns about unfairness, imbalance and asymmetry of information power and reduce customers' feeling of alienation.

Future research can attempt to identify other concerns related to organizational practices that are associated with individuals' feeling of alienation. Future research can also attempt to identify practices related to different models of Internet-based businesses and test how concerns about specific Internet-based business practices affect individual consumers' feeling of alienation in the context of different business models.

\begin{tabular}{|c|c|c|}
\hline & & Appendix A: Survey Questionnaire \\
\hline & & Please indicate how much you agree with the statements presented to you by using the following scale. \\
\hline & & 1. Strongly Disagree 2. Disagree 3. Slightly Disagree 4. Uncertain 5. Slightly agree 6. Agree 7. Strongly Agree \\
\hline Y1.1 & 1234567 & $\begin{array}{l}\text { In the way they design, implement and control students' personal information management systems, most universities care } \\
\text { nothing at all about the student. }\end{array}$ \\
\hline Y1.2 & 1234567 & It is usually an unpleasant experience to have to give personal information to a university. \\
\hline $\mathrm{Y} 1.3$ & 1234567 & Students are unable to determine what uses will be made of the personal information collected about them by a university. \\
\hline Y1.4 & 1234567 & In general, universities are plain dishonest in their dealings with students' personal information. \\
\hline Y1.5 & 1234567 & $\begin{array}{l}\text { Universities stand behind their promises and guarantees made about the ethical standards of students' personal } \\
\text { information management. }\end{array}$ \\
\hline Y1.6 & 1234567 & $\begin{array}{l}\text { In the way they manage information collected from or about student, the student is usually the least important } \\
\text { consideration to most universities. }\end{array}$ \\
\hline \multirow[t]{2}{*}{ Y1.7 } & 1234567 & $\begin{array}{l}\text { As soon as they collect students' personal information, most universities forget about the students' rights, dignity and } \\
\text { well being. }\end{array}$ \\
\hline & & 1. Strongly Disagree 2. Disagree 3. Slightly Disagree 4. Uncertain 5. Slightly agree 6. Agree 7. Strongly Agree \\
\hline $\mathrm{X} 14.1$ & 1234567 & $\begin{array}{l}\text { Data about students stored in multiple files and databases should not be aggregated to build profiles of individual } \\
\text { students. }\end{array}$ \\
\hline $\mathrm{X} 14.2$ & 1234567 & $\begin{array}{l}\text { Unnecessary matchings should not be made with student data stored in different files, databases and transaction records } \\
\text { to create individual profiles (academic,psychological, athletic, disciplinary, library, criminal) of students. }\end{array}$ \\
\hline \multirow[t]{2}{*}{$\mathrm{X} 14.3$} & 1234567 & $\begin{array}{l}\text { Unnecessary comparisons of data in multiple files, databases and records should not be made with student data to create } \\
\text { individual profiles (academic, psychological, athletic, disciplinary, library, criminal) of students. }\end{array}$ \\
\hline & & 1. Strongly Disagree 2. Disagree 3. Slightly Disagree 4. Uncertain 5. Slightly agree 6. Agree 7. Strongly Agree \\
\hline $\mathrm{X} 7.1$ & 1234567 & $\begin{array}{l}\text { The IS problem definition should take into account, in a balanced way, the vital interests and competing claims of all } \\
\text { stakeholders who will be affected by the IS. }\end{array}$ \\
\hline $\mathrm{X} 7.2$ & 1234567 & $\begin{array}{l}\text { System designers and planners should make sure that interests of the information system's different stakeholders have } \\
\text { been justly considered and balanced. }\end{array}$ \\
\hline $\mathrm{X} 7.3$ & 1234567 & I believe that reports involving different stakeholders of a university should contain a balanced presentation of the results. \\
\hline $\mathrm{X} 7.4$ & 1234567 & $\begin{array}{l}\text { I am concerned that reports involving different stakeholders of SIUC do not contain a balanced presentation of the results- } \\
\text { they are biased and unfair. }\end{array}$ \\
\hline
\end{tabular}




\section{REFERENCES}

1 Ackerloff, G.(1970); "The Market for 'Lemons': Quality Under Uncertainty and the Market Mechanism"; Quarterly Journal of Economics; 1970 Issue 84, p488-500, 13p.

2 Allison, Neil K.., "A Psychometric Development of a Test for Consumer Alienation from the Marketplace." Journal of Marketing Research (JMR), Nov78, Vol. 15 Issue 4, p565, 11p

3 Barnard, C. I. (1938) The functions of the executive. Cambridge, M.A: Harvard University Press.

4 Betty A. Kleen; Lynn R. Heinrichs,Are Privacy Policies more Clear and Conspicuous in 2006 than in 2001? A longitudinal Study of the Fortune 100 Issues in Information System, 8 (2) pp. 430-436.

5 Borna, Shaheen; Avila, Stephen; "Genetic information: Consumers' right to privacy versus insurance companies' right to know...” Journal of Business Ethics, May99, Vol. 19 Issue 4, p355, 8p

6 Brookes, Geoff., "From rebellion to class war". Times Educational Supplement, 3/29/2002 Issue 4474, p33, 1/2p;]

7 Cespedes, F. V. and Smith, H. J. "Database Marketing: New Rules for Policy and Practice," Sloan Management Review (34), Summer 1993, pp. 7-22.

8 Culnan, M. J. "'How Did They Get My Name?': An Exploratory Investigation of Consumer Attitudes Toward Secondary Information Use," MIS Quarterly (17:3), September 1993, pp. 341-363.

9 Culnan, Mary J.; Armstrong, Pamela K.., "Information privacy concerns, procedural fairness, and impersonal trust: An empirical investigation." Organization Science: A Journal of the Institute of Management Sciences, Jan/Feb99, Vol. 10 Issue 1, p104, 12p.

10 Date, C.J. An Introduction to Database Systems (4th ed.), Addison-Wesley Publishing Company, Reading, MA, 1986.

11 Dean, Dwight. "Alienation and Political Apathy," Social Forces, 38 (March 1960), 185-9.

12 Donald R. Moscato; Eric D. MoscatoWeb Site Security Disclosure Policie of Online Securities Firms: Are they Satisfactory? Issues in Information System, 8 (2) pp. 303-308.

13 Donaldson, Lex (1995). American anti-management theories of organization: a critique of paradigm proliferation; Cambridge studies in management 25; Cambridge University Press, New York.

14 Drucker, P.F. (1988, January-February). "The coming of the new organization." Harvard Business Review, pp.48-53

15 Freeman, R. E. 1984. Strategic management: A stakeholder approach. Boston: Pitman Publishing.
16 Friedland, Stan., "Less Violence?” Change School Culture.; Education Digest, Sep99, Vol. 65 Issue 1, p6, 4p;

17 Garfinkel, Simson (2000). Database Nation. O’Reilly \& Associates, Inc.

18 Hair, Joseph F. Jr. Anderson, Rolph E.Tatham, Ronald L and Black, William C. Multivariate Data Analysis (1998), fifth edition, Prentice Hall

19 Hancock, Bill; "Student Privacy A Congressional Concern.” Computers \& Security, 2001, Vol. 20 Issue 2, p106

20 Hemphill, Thomas A. "DoubleClick and Consumer Online Privacy: An E-Commerce Lesson Learned.” Business \& Society Review, Fall2000, Vol. 105 Issue 3, p361, 12p

21 Joseph Francom; RFID: A Survey of Ethical and Privacy Concerns, Issues in Information System, 8 (2) pp. 336-340.

22 Karen A. Forcht; Eric Kieschnick; Daphyne S. Thomas; Jack D. ShorterIdentity Theft: The Newest Digital Attack, Issues in Information System, 8 (2) pp. 297-302.

23 Laudon, K.C. Dossier Society: Value Choices in the Design of National Information Systems, Columbia University Press, New York, 1986.

24 Linowes, D. F. Privacy in America: Is Your Private Life in the Public Eye? University of Illinois Press, Urbana, IL, 1989.

25 Marzie Astani; JoEll Bjorke,RapidFrequency Identification Technology and Consumer Privacy, Issues in Information System, 8 (2) pp. 341-347.

26 Mason, R. O. "Four Ethical Issues of the Information Age," MIS Quarterly (10:1), March 1986, pp. 4-12.

27 Mason, Richard O. Mason, Florence M. Culnan, Mary J. Ethics of Information Management. Sage series in business ethics (SSBE). Sage Publications, 1995.

28 Milberg,Sandra J.; Burke, Sandra J.., "Values, personal information privacy, and regulatory approaches." (cover story); Communications of the ACM, Dec95, Vol. 38 Issue 12, p65, 10p

29 Miller, A. "Computers and Privacy," in Ethics and the Management of Computer Technology, W. M. Hoffman, and J. M. Moore (eds.), Oelgeschlager, Gunn, and Hain Publishers, Inc.,Cambridge, MA, 1982.

30 Mollick, Joseph S; (2006) "Do Concerns About Error in Data and Access to Data Affect Students' Feeling of Alienation" Journal of Information Privacy and Security, Vol. 2 (1) pp. 29-48.

31 Mollick, Joseph S; Pearson, John M.(2006) "Effects of Two Information Privacy Concerns on Students' Feeling of Alienation” Journal of International Technology and Information Management, 15 (1) pp. 79-90 
32 Nettler, g.A. “A Measure of Alienation,” American Sociological Review, 22 (December 1957), 870-7.

33 Robert Behling; Wallace WoodLapto Theft: A Growing Concern for Organizations, Issues in Information System, 8 (2) pp. 291-296.

34 Sethna, Beheruz; Barnes, Cynthia C. "E-Mail Communications in Colleges and Universities: Are They Private?”

35 Singh, Jagdip (1988). “Consumer Complaint Intentions and Behaviors: Definitional and Taxonomical Issues,” Journal of Marketing, 52 (January), 93-107.

36 _ (1990) “A typology of Consumer Dissatisfaction Response Styles,” Journal of Retailing, 66 (Spring), 57-97.

37 _ and Robert E. Wilkes (1996), "When Consumers Complain: A Path Analysis of the Key Antecedents of Consumer Complaint Response Estimates," Journal of the Academy of Marketing Science, 24 (Fall), 350-65

38 Simon, H. A. (1976). Administrative behavior (3rd ed.). New York: Mcmillan

39 Smith, H. Jeff; Milberg, Sandra J. "Information privacy: Measuring individuals' concerns about organizational practices." MIS Quarterly, Jun 96, Vol. 20, Issue 2, p167, 30p.

40 Stone, E. F. and Stone, D. L. "Privacy in Organizations: Theoretical Issues, Research Findings, and Protection Mechanisms," in Research in Personnel and Human Resources Management (8), K. M. Rowland and G. R. Ferris (eds.), JAI Press,Greenwich, CT, 1990, pp. 349-411.

41 Stone, E. F., Gardner, D.G., Gueutal, H. G., and McClure, S. "A Field Experiment Comparing Information-Privacy Values, Beliefs, and Attitudes Across Several Types of Organizations," Journal of Applied Psychology (68:3), August 1983, pp. 459468.

42 Studdert, David M.”Direct Contracts, Data Sharing and Employee Risk Selection: New Stakes for Patient Privacy in Tomorrow's Health Insurance Markets.” American Journal of Law \& Medicine, 1999, Vol. 25 Issue 2/3, p233, 33p

43 Thompson, James D (1967). Organizations in action; social science bases of administrative theory; Published: New York, McGraw-Hill

44 Tolchinsky, P.D., McCuddy, M.K., Adams, J., Ganster, D.C., Woodman, R.W., and Fromkin, H.L. "Employee Perceptions of Invasion of Privacy: A Field Simulation Experiment," Journal of Applied Psychology (66:3), June 1981, pp. 308-313.

45 Wang, Huaiqing; Lee, Matthew K.O.; et al. "Consumer privacy concerns about Internet marketing." Communications of the ACM, Mar98, Vol. 41 Issue 3, p63, 8p
46 Westin, A. F. The Dimensions of Privacy: A National Opinion Research Survey of Attitudes Toward Privacy. January,1979. 